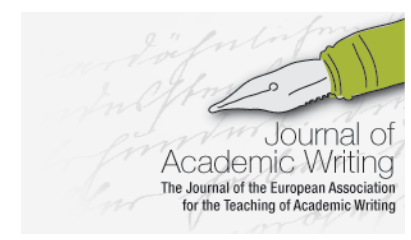

Journal of Academic Writing

Vol. 8 No 2 Wrinter 2018, pages 11-23 http://dx.doi.org/10.18552/joaw.v8i2.472

\title{
Collaborative Learning as Leadership Tool: The Institutional Work of Writing Center Directors
}

Katrin Girgensohn

European University Viadrina, Germany

\begin{abstract}
Writing center directors have to face complex leadership tasks, but often do not have a background in management or administration studies. This study asks how they accomplish this demanding effort. Following a grounded theory approach, 16 writing centers in the USA were visited and expert interviews with the center directors were carried out. In bringing together the emerging concepts of the empirical work with the theoretical framework of the study of institutional work, this article shows that writing center directors transfer the pedagogy of writing centers to their leadership tasks. They use a stance of collaborative learning to deal with the challenges in their everyday work and to institutionalize their writing centers.
\end{abstract}

\section{Introduction}

There has been an exceptional rise in the number of writing centers in Germany in the last decade (Scott 2017). This is reflected in the fact that, while in 2007 there were eight writing centers in total across all German universities, this number now stands at more than 80 (Bromley 2015). ${ }^{1}$ These centers developed in various ways, some through personal engagement of individuals involved in the centers, others with the help of governmental programs like the German 'Quality Pact for Teaching'. ${ }^{2}$ With more and more writing centers opening, a need for practical advice on writing center leadership has evolved. As the director of a German writing center myself, I began to research writing center literature to learn more about how to establish, organize and maintain writing centers. Although I found sources with helpful advice (for example, Murphy and Stay 2006), I was surprised to find only a few sources with recommendations based on systematical research. Among these sources were studies which could be characterized as case studies, such as that by Martha Broekhoff (2014) who generates checklists for implementing writing centers, particularly in developing countries. Several others identify problems typical of writing center directors' work based on quantitative surveys (see for example Valerie Balester and James McDonald 2001). Additionally, a study by Anne Geller and Harry Denny (2013) takes a qualitative approach to analysis of interviews with writing center professionals offering advice on how to achieve better status for writing center directors. And, finally, a study based on both quantitative and qualitative systematical research by Kristine Barnett (2007) offers advice on fundraising, campus alliances and research activities. While all of these sources provide helpful advice, overall, however, there seems to be a gap between the demand of knowledge about writing center leadership and evidencebased research that generates such knowledge.

1 Many of those writing centers can be found in this directory: http://www.unibielefeld.de/Universitaet/Einrichtungen/SLK/schreiblabor/wir und die anderen.html

2 Further information on the German 'Quality Pact for Teaching' is available at: https://rio.jrc.ec.europa.eu/en/library/quality-pact-teaching 
This study narrows this gap. During a one year stay in the USA, financed by the German Research Foundation (DFG), I conducted expert interviews and undertook participant observations in a variety of writing centers. My aim was to gain a more nuanced picture of the everyday work of writing center directors as well as of typical challenges and strategies to deal with them. First, I took an inductive approach, trying not to bring in too many assumptions and prior knowledge. Later on, I compared the concepts that emerged from the data with theoretical perspectives from organizational studies, mainly from neo-institutionalism. This provided me with a theoretical framework in which to embed my research results. The concept of institutional work is particularly helpful to understand and systematize the findings. Therefore, in this article, I will first dedicate a section to introducing this concept, before I summarize the results with regard to the question how writing center directors conduct institutional work.

\section{The concept of institutional work}

The concept of institutional work has become an important topic in organizational studies in recent years (Lawrence, Suddaby and Leca 2009). The word institution, in the way we use it in our everyday life, has the meaning of a public organization, for example, a school or government agency. In a more metaphorical meaning, we call something an institution that is impressive, authoritative, or has seemingly always been there. From a sociological point of view, the term covers both of these meanings. Sascha Koch and Michael Schemann (2009: 20) define institutions as:

- $\quad$ permanent

- objective

- external

- meaningful

- $\quad$ and regulative.

Additionally, institutions are often not recognized consciously, but are taken for granted people do not question them (Walgenbach and Meyer 2008: 60).

Those factors can be true for a material institution, like a university, as well as for an immaterial institution, like a value or behavioral pattern that is shared by large parts of the society, for example - marriage. With regard to a writing center, it might be said that it is an institution the moment it is founded at a university, because it has a public mandate and is part of the university. This does not, however, imply that the writing center fulfills all criteria given above, or will always automatically fulfill them. The building and maintenance of institutions always needs work (Lawrence, Leca and Zilber 2013). And for a writing center, the person responsible for getting this institutional work done is the director. Institutional work is defined as 'purposive action of individuals and organizations aimed at creating, maintaining and disrupting institutions' (Lawrence and Suddaby 2006: 215). This 'purposive action' always aims at other people, because theory of social practices shows that institutions are socially constructed and do not exist independently from social practices. Institutions exist because people do something. For example, the institution 'democracy' only exists through certain social practices, like elections (Lawrence and Suddaby 2006). Therefore, institutional work always has to focus on actors and their social practices related to institutions.

There are two general directions of institutional work. First, institutional work aims at stabilizing an organization, thus pointing at the inside of the institution. Second, institutional work aims at gaining legitimacy for the institution, thus pointing at the context of an institution. In both directions, institutional work happens in interaction with other actors. Institutional workers have to recognize stakeholders and interact with them. For this, institutional workers identify 'Strategic Action Fields' (SAFs) (Fligstein and McAdam 2011). To interact with stakeholders within those SAFs, institutional workers need reflexivity, which allows them to be aware of their contexts and to act strategically (Lawrence and Suddaby 2006). Additionally, they need creativity, to be able to deal with discrepancies, to recognize opportunities and to take advantage of them (Hargrave and Van de Ven 2009). Moreover, they need social skills to be able to interact successfully (Fligstein 1997). 
Based on this, this study investigates the institutional work of writing center directors, asking which SAFs they identify inside the institution and within its contexts and how they interact with stakeholders within those SAFs. The overall goal of the institutional work is the writing center's institutionalization. Based on the above given characteristics of institutions, this leads to the specific goals illustrated in table 1.

Table 1. Goals for the institutionalization of writing centers

\begin{tabular}{|l|l|l|}
\hline $\begin{array}{l}\text { Characteristics } \\
\text { of institutions }\end{array}$ & Institutions in general & Goals for institutionalization of writing centers \\
\hline Permanent & The institution persists & $\begin{array}{l}\text { Sustainable Framework (unlimited contracts, } \\
\text { stable budget, identifiable rooms...) }\end{array}$ \\
\hline Objective & $\begin{array}{l}\text { The existence of the } \\
\text { institution is renowned } \\
\text { by others }\end{array}$ & $\begin{array}{l}\text { The writing center is part of the university's } \\
\text { organigram, is part of the university's marketing } \\
\text { and university members refer to the writing } \\
\text { center }\end{array}$ \\
\hline External & $\begin{array}{l}\text { The existence of the } \\
\text { institution is } \\
\text { independent from social } \\
\text { actors }\end{array}$ & $\begin{array}{l}\text { The writing center persists when directors and } \\
\text { other members change }\end{array}$ \\
\hline Meaningful & $\begin{array}{l}\text { The institution } \\
\text { represents central social } \\
\text { values }\end{array}$ & $\begin{array}{l}\text { The writing center represents central values of } \\
\text { the university with regard to writing (how } \\
\text { writing is taught, how writing is used as tool for } \\
\text { learning, how the university deals with } \\
\text { academic integrity, digital literacies, } \\
\text { multilingual writing and so on) }\end{array}$ \\
\hline Regulative & $\begin{array}{l}\text { The institution } \\
\text { influences social } \\
\text { behavior }\end{array}$ & $\begin{array}{l}\text { The writing center influences the social } \\
\text { behavior of university members with regard to } \\
\text { writing (e.g. how teachers and students deal } \\
\text { with writing assignments) }\end{array}$ \\
\hline $\begin{array}{l}\text { Often } \\
\text { unconscious }\end{array}$ & $\begin{array}{l}\text { The institution is taken } \\
\text { for granted }\end{array}$ & $\begin{array}{l}\text { The necessity for the existence of the writing } \\
\text { center is not questioned }\end{array}$ \\
\hline
\end{tabular}

\section{Methods}

The study followed grounded theory (GT) methodology as proposed by Anselm Strauss and Juliette Corbin (1990). GT methodology aims at developing theory grounded in data. The research process is explorative and iterative. Data collection starts with a fairly open question and goes through several sequences of data gathering, coding and analyzing. This process continues until no new conceptual insights are generated. Strauss and Corbin (1990) call this theoretical saturation.

I conducted 16 expert interviews with writing center directors at different universities in the USA, most of them embedded in participant observations over several days. The term expert interview is a broad one. Bogner, Littig and Menz constitute: 'there is no such thing as the expert interview. The spectrum ranges from quantitative measures through to the use of experts as a form of information source [...] and the theoretically demanding, resolutely qualitative approach' (2009: 6). For this study, I used the latter mentioned qualitative approach that is described and discussed by Michael Meuser and Ulrike Nagel (2009).

An important question for this approach is firstly who would count as an expert? One could argue that every person who is interviewed in any study that aims to reconstruct knowledge on a certain topic would be considered an expert. In this case, any research interview would be an expert interview. This is exactly the reason why expert interviews as a method faced some 
critical debates. For Meuser and Nagel (2009: 18) a person is an expert that 'has knowledge, which he or she may not necessarily possess alone, but which is not accessible to anybody in the field (...)'. Also, the person has to be recognized as an expert within his or her field by others and has to have knowledge that is relevant within an organizational context, such as professional institutions or NGOs (cf. Meuser and Nagel 2009: 18-19). Michaela Pfadenhauer (2009: 83) stresses that persons who are experts not only have an expert knowledge within institutions but furthermore 'can be made responsible for the planning and provision of problem solutions'. Thus, experts are responsible for problem-solving within organizational contexts on the basis of special expertise. Therefore, expert interviews seemed to be a good approach for my study, because I wanted to explore the knowledge of writing center directors concerning solving the problem of how to implement and sustain writing centers successfully within the institutional context of their university or college.

With regard to interview techniques Michaela Pfadenhauer (2009) reminds us that expert interviews are not meant to be interrogations. Neither should they be artificially non-directive, but as far as possible a 'quasi-normal-conversation' (Pfadenhauer 2009: 84). On the other hand, expert interviews aim at comparable answers amongst the conducted interviews. Therefore, I created a topic guide that helped me to ask more or less the same questions in all interviews, but I tried not to stick to it. I only used it to see if all topics I wanted to talk about were covered in our conversations. I explained this to my interview partners in the beginning and encouraged them to ask questions themselves or to go on with whatever they wanted to talk about. My experiences with this kind of interview confirm Pfadenhauer's advice that interviewers in expert interviews should be what she calls 'quasi-experts' to allow conversations on an eye-level that are characterized as follows: 'Thematic focusing, use of professional terminology, deployment of indexical language' (2009: 85). Indeed, I realized that very often the topics I aimed for occurred naturally during our conversations, especially after I had gained more experience and no longer felt nervous. On the other hand, during the coding processes, I sometimes realized that some topics would have profited from more explicit explanations that I did not ask for because of my insider knowledge. The interviews lasted for an average of one hour. I taped them with an audio recorder and saved them as mp3s.

As far as possible, I tried to embed the interviews in participant observations in the writing centers of the interviewed directors. I observed tutoring situations, participated in workshops, tutor educations, staff meetings and other activities, talked to tutors and staff members, browsed documents and media provided in the writing centers and tried to gain a picture of the space of the writing center as well as of the school. Additionally, I often acquired written documents such as annual reports, training materials, internal newsletters, and so on. During these participant observations I took field notes, typed as well as hand-written. I did not include these notes and documents directly in the analysis. However, they clearly helped me to embed and deepen the conversations. I would therefore highly recommend this approach to everyone who wants to conduct expert interviews.

The sample includes a majority of very experienced experts with a directorship experience of 20-30 years. I selected many of them based on their publications within the field of writing center studies. Others were recommended by colleagues. The sample aimed at including a diverse range of universities. It contains nine writing centers at large universities $(>20,000)$, five at smaller ones $(1,200-20,000)$ and two at very small ones $(<1,200)$. Five of those universities are private, eleven public. They include research universities as well as liberal arts colleges, a woman-only college as well as a technical school with $75 \%$ male population, a Catholic university, a university with a high percentage of non-traditional students and a historically black university. The writing centers have between 10 and 110 team members including peer tutors. When I conducted the interviews in 2012, the centers were between nine and 79 years old. All experts agreed voluntarily to participate in the study and signed an informed-consent form.

In accordance with GT methodology, I started coding and analyzing the interviews parallel to conducting and transcribing them. The coding was a recursive process of open coding, axial coding and selective coding that used some paradigmatic questions and techniques suggested by Strauss and Corbin (1990). The software MAXQDA helped me overview the rapidly growing amount of data and to file and connect the intensively written memos. Accordingly, the results 
of the study were discovered through an overall inductive approach. I could distinguish different fields of awareness of writing center directors and a core category that explains how they are able to conduct their work. It was then that I started to read research on organizational studies and found the concept of institutional work useful and surprisingly fitting for my findings. Consequently, I used it as a heuristic to present my findings and tell what Strauss and Corbin (1990) call 'the story' of my data. I present it in the following section.

\section{Results and discussion}

Within the scope of this article I can only present a brief overview of the results. For a more detailed picture see Girgensohn (2017).

\section{Collaborative learning}

As shown above, institutional work is dependent from social skill, reflexivity and creativity. Generally, the study shows that the experts gain those competences from what they have learned and internalized in their pedagogical writing center work. The main result is that they have internalized a stance of collaborative learning and transfer this to their institutional work. In their institutional work, the experts act and interact as collaborative learning practitioners (CLP) in the way Ted Panitz (1999: n.p.) defines this term:

Collaborative learning $(\mathrm{CL})$ is a personal philosophy, not just a classroom technique. In all situations where people come together in groups, it suggests a way of dealing with people which respects and highlights individual group members' abilities and contributions. There is a sharing of authority and acceptance of responsibility among group members for the groups' actions. The underlying premise of collaborative learning is based upon consensus building through cooperation by group members, in contrast to competition in which individuals best other group members. CL practitioners apply this philosophy in the classroom, at committee meetings, with community groups, within their families and generally as a way of living with and dealing with other people.

This means that the experts are constantly involving other people in their processes of developing ideas or making decisions. They encounter those other people assuming that they have an important expertise and that by bringing this expertise together with their own expertise, both parties will be able to construct new knowledge that will be valuable for both sides. Therefore, the experts are empathic, respect and value opinions, and take other people's needs as a starting point for interactions. They are willing to question their own views and to negotiate over long periods, as shown in the following citation from the study:

We, my colleague and I, are in the uncomfortable position now of being in a committee where there are a lot of members who want to find a computer program that will grade essays. [IV laughs] I know. But you see, people from the different disciplines want this. And they think it exists. And so my colleague and I just say, well show us what you have and we will discuss it with you. [...] I don't want to be so close-minded that I say oh no this can't be done. [...] Well, show me what your program can do and I can show you what some of the limitations are. And then let's talk about whether it's a good idea. Maybe it's a good idea for you, in your context. You might like it. I might be using it. ${ }^{3}$

The experts ask open-ended questions to understand concerns and needs, they reframe and mirror their understandings of those concerns and needs, they care for a good atmosphere and at the same time make sure that the conversation will lead to a result in the same way as peer tutors do in writing consultations.

\footnotetext{
${ }^{3}$ All quotations in the results section are taken from the interviews, but are not marked specifically in order to provide the experts' anonymity. Italics mark emphases made by the speakers.
} 
The experts interact as collaborative learning practitioners within SAFs that they identify as important for their institutional work. Data analysis revealed the following Writing Center SAFs (cf. figure 1):

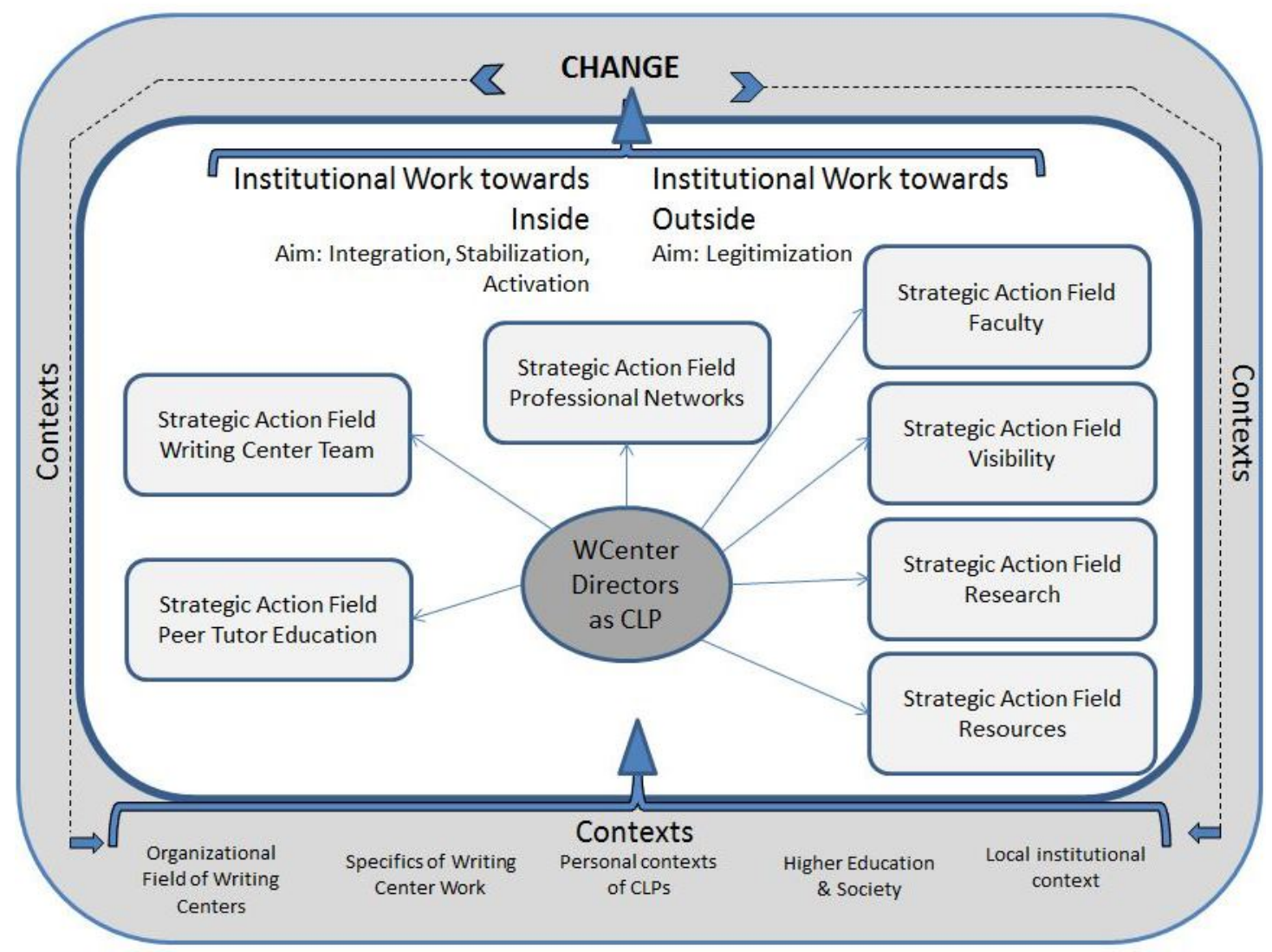

Figure 1. Model of Writing Center Strategic Action Fields (WCSAFs)

\section{Contextual conditions}

In general, it is important to take into account that institutional work is always influenced by contextual conditions. For the experts in my study I identified five categories of influence.

First, the organizational field of writing centers is clearly an important condition. The emergence of an organizational field is seen as important step for institutionalization in institutional theory (DiMaggio and Powell 1983). An organizational field includes several organizations (like writing centers at different universities). It creates norms and has an impact on the definition and structuration of other organizations (like newly founded writing centers). Scott (1994: 207) summarizes:

The notion of field connotes the existence of a community of organizations that partakes of a common meaning system and whose participants interact more frequently and fatefully with one another than with actors outside of the field.

The emergence of an organizational field usually also provides a cognitive foundation that is legitimated by scholars and that is important for a quick diffusion of new ideas and concepts. The study shows that writing center directors today profit from the efforts of former generations to build an organizational field, especially in the way that writing centers seem to be considered as a 'must have' at many universities in the USA - universities need to have writing centers because other universities have them, too. This, of course, is an advantageous condition for institutional work of writing center directors that those outside the USA currently do not often have. 
Other contextual conditions are the specifics of writing center work. The experts face many of the typical challenges known from writing center literature, for example - feelings of marginalization. On the other hand, despite all difficulties, they profit from an enormous intrinsic motivation which results from typical advantages of writing center work, like the opportunity to experience the personal development of student writers and peer tutors without the pressure of grading. My overall impression is that the rewarding aspects overweigh the challenges, because all of the experts were very committed and very positive about their job, like this statement shows:

I feel very lucky to do the work that I do, I feel blessed to do the work that I do and I think is important.

Third, all experts bring parts of their personal contexts into their institutional work. This might be philosophical insights, knowledge from former fields of work or family experiences. This finding underlines what a study of Grover and Miller (2013) revealed about successful leadership in social movements: Leaders deliberately bring in knowledge from other contexts and never stop to seek learning opportunities beyond their usual tasks. Or, as another study states: 'An institutional leader's own life story, thus, enters into the vision formation process along with the life story of the organization itself and its members' (Washington, Boal and Davis 2008: 727).

A fourth contextual condition for institutional work in writing centers is the university system within the society. Being an outsider of the US higher education system, this became obvious to me in the context of certain details. For example, the idea of student services is more natural in the US than it is in Germany, where students do not have to pay for their studies. Also, hierarchies in US higher education seem to be shallower on the first sight, but on the other hand university governance seems to have more top-down influence than in the German system.

Finally, the local contexts of each writing center influence the institutional work heavily. This observation has often been made in writing center literature and became obvious during the study, too, as this citation shows:

What I think what is interesting about writing center work is you can listen to a whole bunch of different people and read stuff and read Kenneth Bruffee or whatever, but finally you are the one on that site and what's gonna be created for your school is gonna be unique.

\section{Writing center strategic action fields inside the writing center}

Towards the inside of the writing center, the institutional work aims at stabilizing the writing center as organization and at motivating others to contribute to the institutional work. One important WCSAF is therefore the writing center team, including all staff members and peer tutors. Here, collaborative learning is used to find and to select team members as well as to organize the everyday work.

For the organization of the everyday work with collaborative learning, some factors seem to be important. For example, the experts need to be attentive and to observe thoroughly what is going on: 'I'd like to observe when things develop and much how they develop and that's why I think of myself more as an observer [than a leader]'.

Additionally, the experts care for creating opportunities for interaction and communication within the team. They build organizational structures that facilitate interaction between different groups; set up offices in a way that fosters communication; set colleagues cc in their e-mails; throw parties or organize excursions, and encourage others to interrupt them, like this expert does in an e-mail to his team:

please, please don't hesitate to interrupt. I'm interruptible. I want to be interrupted. I want to be available to talk with you. I really mean it. Don't think twice, just knock. If the door is closed, please knock to see if I'm around. I really mean it. I do *not* want you 
to feel as if you have to schedule an appointment in advance to chat with me briefly. Seeing and talking with you will always be very high priorities to me.

Another factor is that the experts try to sponsor the talents of their team members. They look at them, as one expert calls it, 'in developmental terms'. This also includes that the experts care for professional development opportunities for their teams.

It is also important for the experts to share responsibility as well as authority, as the following citation illustrates:

So the way we do the writing center now, which I have developed through having lots of different colleagues over time, is that we share some parts of the work across the board. Like the work that nobody wants to do that is very paperworkish. [...] As the director I could just say I don't want to do any of the paperwork, somebody else has to do it. But then I feel like the people that I work with are not really my peers and I want peers to collaborate with.

This way of sharing work is also true for working with peer tutors. The experts collaborate with them for developing policies, handouts, workshops, tutor education units, public relation strategies and so on. Some writing centers let the peer tutors conduct the hiring processes of the new tutors; others create special leadership positions for them or include them in research projects.

The second important SAF within the writing center is peer tutor education. Here, collaborative learning is not only an important content, but also a way to organize and conduct peer tutor education, for example when peer tutors mutually educate and mentor each other.

\section{Writing center strategic action fields outside the writing center}

Towards the writing center's context, the institutional work aims at gaining legitimacy from other stakeholders.

\section{Working with faculty}

This turned out to be an important WCSAF. The experts address faculty to explain the writing center, to seek alliances, and to install changes in the learning culture of the university. Collaborative learning is an important tool to win the faculty's trust, as this example demonstrates:

That means a lot of one-on-one conversations, e-mails. So it might start with a really frustrating e-mail where they write an e-mail and they say: My student came to the writing center and there are still grammar errors in her paper. Could you please explain why? And I say yes, as a matter of fact, we can. And I will. And just explain it. And try not to even let one hint of defensiveness come in, just have those conversations. [...] So if I have a conversation about a student, at the end of it I'll say something like I have really enjoyed talking with you about this and if other things come up in future that are confusing, I hope you pick up the phone and call me or just come by anytime, we'd love to talk about your students, your assignments. Sometimes l'Il throw in ESL students, plagiarism, whatever else he might be concerned about. Just like here are the things you can bring here. And over time it builds up. [...] It's good and I think that in the long run that's where a lot of the work has to happen.

An interesting detail here is that the expert takes care to not be defensive. Conversations like this are opportunities for her to gain legitimacy, but they need to take place at eye-level, otherwise collaborative learning could not take place. She starts the conversation with the actual need of the other actor, but also uses it to demonstrate her own expertise in other fields that might be of interest for the teacher.

\section{Visibility}

The experts dedicate many resources to the WCSAF visibility, because they 'don't want the good work we do and the influence we have on students and faculty to be invisible', as one of 
them explains. Within this WCSAF, institutional work includes developing public relations material, like print media or the homepage. For this, the experts rely on advice from others; they become creative and are very aware of their rhetorical instruments. They also care about communication opportunities with other stakeholders. For example, they volunteer for committees in different institutional contexts or create advisory boards for their own programs. The physical space of the writing center is also part of the strategic action field visibility. The location of the writing center, as well as its appearance, creates an opportunity to educate others about writing center work and the importance of getting, or having, adequate space:

The academic dean [...] knows nothing about writing centers. So she is a very smart person, but with regard to a minimum knowledge of what this culture is like and how it works and what kind of things you can or can't do, I mean, for our writing center location is very important. Where we are located. The nature of the space. [...] And so that was one area that the dean really hadn't thought through. So her initial suggestion with regard to the location of the writing center was not where we are located now and would have been really difficult. It was several months [...] of pretty serious argument back and forth.

The question of location can also be seen in a more metaphorical way: where in the university structure is the writing center located? Is it part of a department, a service-unit, a library? To whom does the writing center report? All possibilities have their pros and cons and obviously there is no one-fits-all-solution. However, it is important to include these considerations into the strategic action field, because the university context does not provide a stable status quo. It might be the case that in the future presidents or deans decide to move the writing center to another place in the organigram or merge it with other units. Also, it might be worth thinking of trying to move the writing center to units with more resources or more adequate space.

\section{Research}

Conducting and publishing research might be seen as a visibility strategy, but furthermore it is used to mark the writing center as an academic institution and to enhance the quality of the writing center's work - both important for gaining legitimacy in a university context. Within this WCSAF, the experts tend to use collaborative learning to make research happen, although they have a very high workload that restricts time and energy for research projects. They collaborate on research projects with colleagues of other writing centers; with faculty from various departments; and with peer tutors. They expand writing center assessments with support of experts that are familiar with research methods and they implement structures that allow - and urge - their team members to read current writing center literature.

\section{Resources}

To gain, stabilize and enhance resources, the experts collaborate in various ways, for example with different university units or alumni. The experts tend to see themselves as entrepreneurs:

You run a business within a large business, you know, the institution. You constantly try to get money from the large business, try to find out who are the ones with the money.

To 'get money from the large business', collaborative learning can help to find out what other stakeholders in the university need. Like entrepreneurs, the experts do not want to offer things that no one needs or wants. They conduct 'market research', as one of the experts explains: 'Market research really means going out and finding out if it's possible to offer the things you want to offer'. Examples of successful results of 'market research' are collaborations with dorms, libraries or distance education programs, which pay for expansion of the facilities and support that the writing center's offers when it meets their needs.

\section{A writing center strategic action field in-between: professional networks}

Professional networks are a WCSAF that addresses both the inside of the writing center as well as its context. As shown above, the organizational field of writing center work is an important contextual condition for the directors' institutional work. The existence of this field does not only require universities to have writing centers. It also provides important resources. Writing center 
directors can refer to professional organizations like the International Writing Centers Association (IWCA), use resources like the wcenter-listserv, get knowledge from diverse publications like the writing center journal, and network at various conferences.

Towards the inside of the writing center, the existence of the field helps the experts to get advice and support for evolving issues. It also provides the whole writing center team with possibilities for identification. When they participate in conferences, publish or discuss articles or rely on certain theoretical backgrounds, this helps to stabilize and motivate the team. It also helps to provide an image of coherence and solidity towards the outside, which is an important goal of institutional work.

Towards the center's context, the participation in professional networks marks the writing center as an organization with a professional identity and with all of the markers of an academic institution, like conferences, publications, shared state of research and so on. The study clearly shows that this is very important for writing centers and that current centers profit immensely from efforts of former generations that established those markers. Thus, involvement in professional communities also helps to keep writing centers sustainable for the future. It should therefore be a conscious part of the everyday work of writing center directors.

\section{The outcome of institutional work: change}

Institutional work always aims at change. Writing center directors want to change the university context towards the institutionalization of the writing center. In the meantime, they have to maintain the status quo of their center's institutionalization and they have to prevent possible deinstitutionalizations. Therefore, it is important to be aware constantly of possible or ongoing changes, be it to initiate new programs or be it to avoid setbacks. As one expert explains, it is very important for institutional work to not become careless when a seemingly high level of institutionalization has been established:

I think that because I have been at this university for such a long time and I had such a strong base of support within the faculty of this department, that I became careless about it, you know. I was assuming that it was there and then there was this huge turnover. A lot of my colleagues retired, some of them left and went to other universities and then we got a new dean and a new department head. And all of the sudden things shifted. Within the department I sense that, you know, there is a lot of change going on. And there are some old buried issues, maybe some resentment about the power that composition and writing had in this department for a very long time and you know, they are coming to the surface now.

Also, it seems to be important to be proactive in initiating new programs when curriculums, student populations or expectations in higher education change. In other words: The need for institutional work in the writing center will never end. However, this can be seen as a positive feature of the writing center director's work, as this expert claims: 'So you have to be willing to constantly negotiate those things. It makes the job very interesting [laughs]'.

\section{Conclusion}

The study shows that writing center directors - although usually not trained for organization management tasks - have a mighty and valuable tool for their institutional work, when they act as collaborative learning practitioners. A deliberate use of collaborative learning for leadership can provide success in institutional work. Therefore, in difficult situations as well as in everyday routines, it might be helpful to step back and reflect on what collaborative learning would implicate in this very moment. In other words: collaborative learning should be used consciously and on purpose.

Another conclusion is that it is important for writing center directors to be aware of the variety of WCSAFs. All of them are important - and there will probably be more, or other, WCSAFs at other writing centers. Being aware of this variety and the different WCSAF implications can help writing center directors to oversee workload and to argue for more resources. 
Overall, however, it must be said that even the most conscious and engaged institutional work does not necessarily lead to success, because it is embedded in very complex and continually changing contexts. Even some of the most experienced writing center directors in my study, widely recognized in the field of writing center work and with demonstrated success in their home institutions with regard to numbers and acknowledgments, had to face some severe disappointments, like budget cuts or reduction of important parts of their centers. I see another analogy to writing center pedagogies here: We know that writing is difficult and that being a successful writer does not mean to not have writing problems, but to deal successfully with upcoming problems. This is what we hope writers learn when they make use of the facilities and support that a writing center offers. The same is true for the difficult task of writing center leadership: It is not important to not have problems, but to deal with them successfully. As in writing center tutorials, collaborative learning will support this.

A limitation of this study with regard to Europe is its contextualization in the US-American university system. It should therefore be considered more as a beginning than as a completed research project, connected with an invitation to join this conversation. The rise of writing centers in European higher education should make it possible by now to continue this research here and I am looking forward to hearing from other European writing centers' investigations on their WCSAFs. ${ }^{4}$

\footnotetext{
4 The EU COST Action 15221 'Advancing effective institutional models towards cohesive teaching, learning, research and writing development' is currently following up on this research in several short term scientific missions, see www.werelate.eu.
} 


\section{References}

Balester, V., and McDonald, J. C. (2001) 'A View of Status and Working Conditions: Relations between Writing Program and Writing Center Directors'. Writing Program Administration 24 (3), 59-82

Barnett, K. M. (2007) Leading College Writing Centers into the Future: Strategies for Survival and Sustainability. Dissertation. Longmeadow, MA: Johnson and Wales University

Bogner, A., Littig, B., and Menz, W. (eds.) (2009) Interviewing Experts. Basingstoke: Palgrave Macmillan

Broekhoff, M. (2014) 'A Tale of Two Writing Centers in Namibia: Lessons for Us All'. Journal of Academic Writing 4 (1), 66-78

Bromley, P. (2015) 'Transatlantic Perspectives on Writing Centers. Preliminary Findings from the International Writing Centers Research Project (IWCRP)'. EATAW Conference 2015. held 15-17 June at Talinn University of Technology. Talinn, Estonia: Unpublished

Corbin, J. and Strauss, A. (1990) Basics of Qualitative Research: Grounded Theory Procedures and Techniques. 2nd edn. London: Sage

DiMaggio, P. J., and Powell, W. W. (1983) 'The Iron Cage Revisited: Institutional Isomorphism and Collective Rationality in Organizational Fields'. American Sociological Review 48 (2), 147-160

Fligstein, N. (1997) 'Social Skill and Institutional Theory'. American Behavioral Scientist 40 (4), 397-405

Fligstein, N., and McAdam, D. (2011) 'Toward a General Theory of Strategic Action Fields'. Sociological Theory 29 (1), 1-26

Geller, A. E., and Denny, H. (2013) 'Of Ladybugs, Low Status, and Loving the Job: Writing Center Professionals Navigating Their Careers'. The Writing Center Journal 33 (1), 96129

Girgensohn, K. (2017) Von der Innovation zur Institution. Institutionalisierungsarbeit an Hochschulen am Beispiel der Leitung von Schreibzentren. Bielefeld: Bertelsmann W. [online] available from <www. oapen.org/download?type=document\&docid=640952> [9 October 2018]

Grover, K. S., and Miller, M. T. (2013) 'Citizen Use of Self-Directed Learning Strategies: Differences between Leaders and Non-Leaders'. Journal of Organizational Learning and Leadership. [online] 11 (1), 37-46. available from <http://www.leadingtoday.org/weleadinlearning/Spring2013/Spring_Summer_2013_G rover.pdf $>$ [9 October 2018]

Hargrave, T. J., and Van de Ven, A. H. (2009) 'Institutional Work as Creative Embrace of Contradiction'. in Institutional Work: Actors and Agency in Institutional Studies of Organizations. ed. by Lawrence, T., Suddaby, R., and Leca, B. Cambridge: Cambridge University Press, 120-140

Koch, S., and Schemmann, M. (2009) 'Entstehungskontexte und Grundlagen NeoInstitutionalistischer Organisationsanalyse'. in Neo-Institutionalismus in der Erziehungswissenschaft. ed. by Koch, S. and Schemmann, M. Wiesbaden: VS Verlag für Sozialwissenschaften, 20-27

Lawrence, T., Leca, B., and Zilber T. B. (2013) 'Institutional Work: Current Research, New Directions and Overlooked Issues'. Organization Studies 34 (8), 1023-1033 
Lawrence, T., and Suddaby, R. (2006) 'Institutions and Institutional Work'. in Sage Handbook of Organization Studies. ed. by Clegg, S. R., Hardy, C., Lawrence, T., and Nord, W.R. 2nd edn. London: Sage, 215-254

Lawrence, T., Suddaby, R., and Leca, B. (eds.) (2009) Institutional Work: Actors and Agency in Institutional Studies of Organizations. Cambridge: Cambridge University Press

Meuser, M., and Nagel, U. (2009) 'The Expert Interview and Changes in Knowledge Production'. in Interviewing Experts. ed. by Bogner, A., Littig, B., and Menz, W. Basingstoke: Palgrave Macmillan, 17-42

Murphy, C., and Stay, B. L. (2006) The Writing Center Director's Resource Book. Mahwah, NJ: Lawrence Erlbaum Associates

Panitz, T. (1999) A Definition of Collaborative vs Cooperative Learning. [online] 1-13. available from <http://files.eric.ed.gov/fulltext/ED448443.pdf> [22 February 2013]

Pfadenhauer, M. (2009) 'At Eye Level: The Expert Interview - A Talk Between Expert and Quasi-Expert'. in Interviewing Experts. ed. by Bogner, A., Littig, B., and Menz, W. Basingstoke: Palgrave Macmillan, 81-97

Scott, A. (2017) 'We Would be Well Advised to Agree On Our Own Basic Principles. Schreiben as an Agent of Discipline-Building in Writing Studies in Germany, Switzerland, Austria, and Liechtenstein'. Journal of Academic Writing 7 (1), 43-58

Scott, W. R. (1994) 'Conceptualizing Organizational Fields: Linking Organizations and Societal Systems'. in Systemrationalität und Partialinteresse. ed. by Derlien, H-U., Gerhardt, U., and Scharpf, F.W. Baden-Baden: Nomos, 202-221

Walgenbach, P., and Meyer, R. (2008) Neoinstitutionalistische Organisationstheorie. Stuttgart: Kohlhammer

Washington, M., Boal, K. B., and Davis, J. N. (2008) 'Institutional Leadership: Past, Present, and Future'. in The SAGE Handbook of Organizational Institutionalism. ed. by Greenwood, R., Oliver, C., Suddaby, R., and Sahlin, K. London: Sage, 721-735 